\title{
Production of (S)-3-chlorolactaldehyde from $(S)-\alpha-$ chlorohydrin by boar spermatozoa and the inhibition of glyceraldehyde 3-phosphate dehydrogenase in vitro
}

\author{
D. Stevenson and A. R. Jones \\ Department of Biochemistry, University of Sydney, Sydney, New South Wales, 2006, Australia
}

\begin{abstract}
Summary. The $(S)$-isomer of the male antifertility agent $\alpha$-chlorohydrin was metabolized by mature boar spermatozoa in vitro to $(S)$-3-chlorolactaldehyde. This oxidative process, which did not occur when $(R)-\alpha$-chlorohydrin was offered as a substrate, was catalysed by an $\mathrm{NADP}^{+}$-dependent dehydrogenase that converts glycerol to glyceraldehyde. $(S)$-3-chlorolactaldehyde, produced by this metabolic reaction or when added to suspensions of boar spermatozoa, was a specific inhibitor of glyceraldehyde 3-phosphate dehydrogenase as assessed by the accumulation of fructose 1,6-bisphosphate and the triosephosphates. When glycerol and $(S)-\alpha$-chlorohydrin were added concomitantly to boar spermatozoa in vitro, the presence of glycerol decreased the degree of inhibition of glyceraldehyde 3-phosphate dehydrogenase. Extracts of glyceraldehyde 3-phosphate dehydrogenase that were obtained from boar spermatozoa incubated with $(S)$ - $\alpha$-chlorohydrin or $(R, S)$-3-chlorolactaldehyde showed significant reductions in their enzymic activity.
\end{abstract}

\section{Introduction}

The action of $\alpha$-chlorohydrin (3-chloropropan-1,2-diol) as a male antifertility agent has been investigated in many species in vivo and with spermatozoa in vitro (see Jones, 1978, 1983). The mechanism of its action, which has been deduced from studies involving spermatozoa obtained from the ram (Brown-Woodman, Mohri, Mohri, Suter \& White, 1978), boar (Hutton, Dawson \& Jones, 1980), rhesus monkey, rat, hamster and man (Ford, Harrison, Takkar \& Waites, 1979), involves the inhibition of the glycolytic enzyme glyceraldehyde 3-phosphate dehydrogenase (EC 1.2.1.12). This causes a decrease in the glycolytic flux which limits the ability of the spermatozoa to synthesize ATP. Consequently, when they are ejaculated, the affected spermatozoa have diminished motility and fertilization cannot occur.

The (S)-enantiomer of $\alpha$-chlorohydrin ( $I$, Text-fig. 1) possesses the antifertility response in vivo and the antiglycolytic action in vitro whilst the $(R)$-enantiomer is completely ineffective (see Jones,
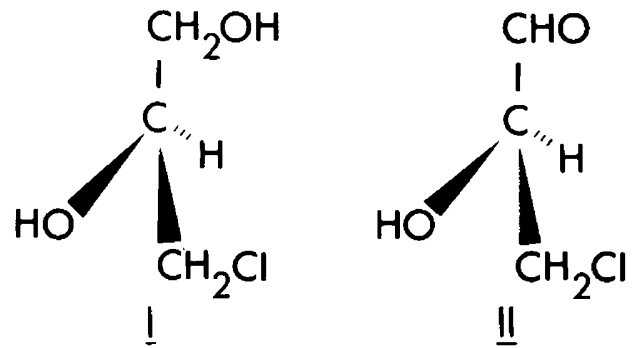

Text-fig. 1. The structures of $(S)$ - $\alpha$-chlorohydrin $(I)$ and $(S)$-3-chlorolactaldehyde $(I I)$. 
1983). The (S)-isomer is not the inhibitory compound per se but it undergoes oxidation within mature spermatozoa to an active metabolite, $(S)$-3-chlorolactaldehyde (II, Text-fig. 1), which possesses the same stereochemistry as $(R)$ - or (D)-glyceraldehyde-3-phosphate, the substrate for the inhibited enzyme (Stevenson \& Jones, 1982).

In this paper we present evidence that this biotransformation within mature boar spermatozoa is performed by an NADP+-dependent dehydrogenase that is involved in the metabolism of glycerol. In addition, the activity of glyceraldehyde 3-phosphate dehydrogenase was measured in boar spermatozoa that had been incubated with $(S)$ - $\alpha$-chlorohydrin or $(R, S)$-3-chlorolactaldehyde.

\section{Materials and Methods}

Chemicals and substrates. $(R)$ - and $(S)-\alpha$-chlorohydrin (Porter \& Jones, 1982$)$ and $(R, S)-\left[3-{ }^{36} \mathrm{Cl}\right]-\alpha-$ chlorohydrin (sp. act. $240 \mu \mathrm{Ci} / \mathrm{mmol}$ ) (Jones, 1975) were synthesized to confirmed purity by established procedures. $(R, S)$-3-chlorolactaldehyde was prepared by the method of Williams, Payne, Sullivan \& Van Ess (1960). D- $\left[U-{ }^{14} C\right]$ Fructose, L-[U-14 C]lactate, $\left[1-{ }^{14}\right.$ C $]$ pyruvate, [U$\left.{ }^{14} \mathrm{C}\right]$ glycerol and $\left[\mathrm{U}^{-14} \mathrm{C}\right] \mathrm{glycerol} 3$-phosphate were purchased from Amersham International plc (Amersham HP7 9LL, U.K.). All enzymes, substrates and co-factors were obtained from Sigma Chemical Co. (St Louis, Missouri 63178, U.S.A.). All other chemicals and reagents were of analytical grade and all solutions were prepared in glass-distilled deionized water.

Metabolic studies. For each experiment, spermatozoa were obtained from each cauda epididymidis of 15-20 mature boars (Sus scrofa) within $1.5 \mathrm{~h}$ of slaughter at the abattoir. Suspensions of washed spermatozoa were prepared at a concentration of $2-3 \mathrm{~g} / 10 \mathrm{ml}(20-35 \mathrm{mg}$ protein $/ \mathrm{ml}$ or $\sim 10^{8}$ cells $/ \mathrm{ml}$ ) in modified phosphate-buffered saline (PBS) (Stevenson \& Jones, 1982). Only those samples observed by microscopic examination to contain $>90 \%$ motile spermatozoa were used in the metabolic studies. Incubations were performed in stoppered Warburg flasks shaken at $120 \mathrm{cycles} / \mathrm{min}$ at $34^{\circ} \mathrm{C}$ for $1 \mathrm{~h}$, each incubate containing washed spermatozoa $(0.9 \mathrm{ml}),(S)$ - $\alpha$-chlorohydrin, $(R, S)$-3-chlorolactaldehyde or PBS $(0.05 \mathrm{ml})$ and radioactive substrate $(50 \mathrm{nCi}, 0.05 \mathrm{ml})$ at the concentrations indicated in Table 1. Metabolicallyderived ${ }^{14} \mathrm{CO}_{2}$ was collected (Dawson, 1977) and assayed in a Beckman model LB3800 liquid scintillation counter (Stevenson \& Jones, 1982). Neutralized and deproteinized incubation solutions (Stevenson \& Jones, 1982) were used for the assay of fructose 1,6-bisphosphate, dihydroxyacetone phosphate and glyceraldehyde 3-phosphate by the method of Michal \& Beutler (1975). Protein was estimated (Lowry, Rosebrough, Farr \& Randall, 1951) using bovine serum albumin as a standard and the results were calculated using the linear transform equation of Coakley \& James (1978).

Spectrophotometric studies. Enzyme activities were assayed in a Varian 634 spectrophotometer by following the change in absorbance at $340 \mathrm{~nm}$ corresponding to the oxidation or reduction of nicotinamide coenzymes. The conditions used were those of O'Brien \& Schofield (1980) (for aldose reductase activity) and Kormann, Hurst \& Flynn (1972) (for NADP+-dependent dehydrogenase activity).

Isolation of aldose reductase(s) from boar spermatozoa. Samples of boar spermatozoa (10-30 g) were collected in and washed with $20 \mathrm{~mm}$-sodium phosphate buffer ( $\mathrm{pH} \mathrm{7.4)} \mathrm{containing} 5 \mathrm{mm-}$ mercaptoethanol. The sedimented spermatozoa were suspended in 4 volumes of distilled water and disrupted by sonic oscillation $\left(20 \mathrm{kHz}\right.$ for $10 \mathrm{~min}$ at $4^{\circ} \mathrm{C}$ ). This suspension was processed by the method of O'Brien \& Schofield (1980) to the stage of $60 \%\left(\mathrm{NH}_{4}\right)_{2} \mathrm{SO}_{4}$ saturation, the precipitate was dissolved in $10 \mathrm{~mm}$-sodium phosphate $(\mathrm{pH} \mathrm{7.2)}$ and this solution was used for spectrophotometric studies.

Isolation of an $\mathrm{NADP}^{+}$-dependent dehydrogenase from boar spermatozoa. Suspensions of boar spermatozoa in PBS were disrupted by sonic oscillation and processed by the method of Kormann 
et al. (1972) to the stage of $80 \%\left(\mathrm{NH}_{4}\right)_{2} \mathrm{SO}_{4}$ saturation. The precipitate was dissolved in $50 \mathrm{mM}$ sodium phosphate ( $\mathrm{pH} \mathrm{7.0)}$ ) and dialysed against 100 volumes of $10 \mathrm{mM}$-sodium phosphate ( $\mathrm{pH} 7 \cdot 0$ ) at $4-6^{\circ} \mathrm{C}$ for $40 \mathrm{~h}$. The dialysate was concentrated to $50 \%$ volume by ultrafiltration and used in the spectrophotometric studies. Reaction flasks containing the dialysate $(3 \mathrm{ml}), 100 \mathrm{mM}$-sodium phosphate $(\mathrm{pH} 7.0,3.75 \mathrm{ml}), \mathrm{NADP}^{+}(0.4 \mathrm{mM})$ and $\left[\mathrm{U}^{-14} \mathrm{C}\right] \mathrm{glycerol}(100 \mathrm{mM})$ or $(R, S)-[3-36 \mathrm{Cl}]-\alpha-$ chlorohydrin $(100 \mathrm{mM})$ in a total volume of $7 \mathrm{ml}$ were incubated at $34^{\circ} \mathrm{C}$. After $4 \mathrm{~h}, 2,4-$ dinitrophenylhydrazine reagent $(2 \mathrm{ml})$ was added to each flask. $\left[\mathrm{U}-{ }^{14} \mathrm{C}\right]$ Glyceraldehyde or [3${ }^{36} \mathrm{Cl}$ ]chlorolactaldehyde (of unknown configuration) were isolated from the incubates as their 2,4-dinitrophenylhydrazones (Jones, Stevenson, Hutton \& Dawson, 1981).

Assay of glyceraldehyde 3-phosphate dehydrogenase activity. Suspensions of washed boar spermatozoa $(5 \mathrm{ml})$ were incubated at $34^{\circ} \mathrm{C}$. The substrates were either D-fructose $(1 \mathrm{mM})$ or glycerol $(10 \mathrm{mM})$ and the incubates contained $(S)$ - $\alpha$-chlorohydrin $(0.5 \mathrm{mM}),(R)$ - $\alpha$-chlorohydrin $(10 \mathrm{mM})$ or $(R, S)$-3-chlorolactaldehyde $(5 \mathrm{mM})$. After $1 \mathrm{~h}$, these incubations, together with the appropriate control incubations, were centrifuged at $3000 \mathrm{~g}$ for $5 \mathrm{~min}$ at $4^{\circ} \mathrm{C}$. The sperm pellets were suspended in $1.25 \mathrm{ml}$ sucrose $(0.25 \mathrm{M})$ containing EDTA $(1 \mathrm{mM})$ and disrupted by sonic oscillation $(20 \mathrm{kHz})$ at $4^{\circ} \mathrm{C}$ in $0.5-\mathrm{min}$ bursts for a total of $5 \mathrm{~min}$. The suspensions were centrifuged at $20000 \mathrm{~g}$ for $10 \mathrm{~min}$ at $4^{\circ} \mathrm{C}$ and the supernatant solutions were used for assays of glyceraldehyde 3-phosphate dehydrogenase activity by the method of Velick (1955).

\section{Results}

Inhibition of the oxidation of substrates to $\mathrm{CO}_{2}$

The effects of $(S)$ - $\alpha$-chlorohydrin or $(R, S)$-3-chlorolactaldehyde on the oxidation of various ${ }^{14} \mathrm{C}$ labelled substrates to ${ }^{14} \mathrm{CO}_{2}$ by boar spermatozoa are summarized in Table 1. A high concentration $(5 \mathrm{mM})$ of $(S)-\alpha$-chlorohydrin had no effect on the oxidative metabolism of lactate or pyruvate but

Table 1. The effect of $(S)-\alpha$-chlorohydrin $(\mathrm{S} \alpha \mathrm{Cl})$ and $(R, S)$-3-chlorolactaldehyde $(\mathrm{RS} 3 \mathrm{CL})$ on the oxidative metabolism of various ${ }^{14} \mathrm{C}$-labelled substrates to ${ }^{14} \mathrm{CO}_{2}$ by boar spermatozoa for $1 \mathrm{~h}$ at $34^{\circ} \mathrm{C}$

\begin{tabular}{|c|c|c|c|c|}
\hline \multicolumn{2}{|c|}{ Substrate } & \multicolumn{2}{|c|}{ Inhibitor (mM) } & \multirow{2}{*}{$\begin{array}{l}\mathrm{CO}_{2} \text { produced } \\
(\% \text { of control }) \dagger\end{array}$} \\
\hline${ }^{14} \mathrm{C}$-labelled & Unlabelled & $\mathrm{S} \alpha \mathrm{Cl}$ & RS3CL & \\
\hline Lactate (2 mM) & - & 5 & 0 & $121 \pm 7 \cdot 8$ \\
\hline Pyruvate ( $2 \mathrm{~mm}$ ) & - & 5 & 0 & $99.3 \pm 5.5$ \\
\hline Fructose (1 mM) & - & 0.5 & 0 & $14.8 \pm 6.0^{* * *}$ \\
\hline Fructose $(1 \mathrm{mM})$ & - & 0 & 5 & $41 \cdot 8 \pm 9 \cdot 3^{*}$ \\
\hline Glycerol (2 mM) & - & 0.5 & 0 & $120 \pm 10 \cdot 5$ \\
\hline Glycerol (2 mM) & - & 0 & 5 & $12.4 \pm 1.8^{* *}$ \\
\hline Fructose (1 mM) & Glycerol (1 mM) & 0.5 & 0 & $87.5 \pm 5.8$ \\
\hline Fructose (1 mM) & Glycerol (10 mM) & 0.5 & 0 & $91 \cdot 7 \pm 2.6$ \\
\hline Fructose (1 mM) & Glycerol (1 mM) & 0 & 5 & $28 \cdot 2 \pm 4 \cdot 1^{* * *}$ \\
\hline Fructose $(1 \mathrm{mM})$ & Glycerol $(10 \mathrm{~mm})$ & 0 & 5 & $22 \cdot 4 \pm 1 \cdot 3^{* * *}$ \\
\hline Glycerol 3-phosphate (2 mM) & - & 0.5 & 0 & $19 \cdot 4 \pm 2 \cdot 5^{* * *}$ \\
\hline Glycerol 3-phosphate (2 $\mathrm{mM})$ & - & 0 & 5 & $10 \cdot 3 \pm 0 \cdot 24^{* * *}$ \\
\hline Glycerol 3-phosphate (2 mM) & Glycerol (1 mM) & 0.5 & 0 & $93.6 \pm 12.7$ \\
\hline Glycerol 3-phosphate (2 mM) & Glycerol (10 mM) & 0.5 & 0 & $121 \pm 15 \cdot 2$ \\
\hline Glycerol 3-phosphate (2 mM) & Glycerol (1 mM) & 0 & 5 & $9.3 \pm 0.51^{* * *}$ \\
\hline Glycerol 3-phosphate (2 mM) & Glycerol (10 mM) & 0 & 5 & $6.2 \pm 0.56^{* * *}$ \\
\hline
\end{tabular}

Values are mean \pm s.e.m. for 4 separate experiments.

$\dagger$ The results for each particular substrate were compared to control incubations containing that substrate with an equivalent volume of PBS replacing the solution of inhibitor.

${ }^{*} \boldsymbol{P}<\mathbf{0 . 0 2},{ }^{\boldsymbol{*} *} \boldsymbol{P}<\mathbf{0 . 0 1},{ }^{\boldsymbol{*} * \boldsymbol{*}} \boldsymbol{P}<\mathbf{0 . 0 0 1}$ (Student'soldest):rom Bioscientifica.com at 04/26/2023 11:30:41AM 
$0.5 \mathrm{~mm}-(S)-\alpha$-chlorohydrin inhibited the oxidation of fructose and glycerol 3-phosphate. The inhibition was reduced when $1 \mathrm{mM}$ unlabelled glycerol was present and was abolished by $10 \mathrm{~mm}$ glycerol. When $5 \mathrm{~mm}-(R, S)-3$-chlorolactaldehyde was present, the oxidation of fructose, glycerol and glycerol 3-phosphate was inhibited. However, the presence of $10 \mathrm{~mm}$ unlabelled glycerol did not overcome the inhibition of the oxidation of fructose or glycerol 3-phosphate.

\section{Accumulation of glycolytic intermediates}

In the particular incubations in which an inhibition was demonstrated (Table 1) there was an accumulation of fructose 1,6-bisphosphate, dihydroxyacetone phosphate and glyceraldehyde 3phosphate compared to the matching controls. This accords with an action involving the inhibition of glyceraldehyde 3-phosphate dehydrogenase (Table 2).

Table 2. Amounts of fructose 1,6-bisphosphate (FBP), dihydroxyacetone phosphate (DHAP) and glyceraldehyde 3-phosphate (G3P) in boar spermatozoa incubated for $1 \mathrm{~h}$ at $34^{\circ} \mathrm{C}$ in the presence or absence of $0.5 \mathrm{~mm}-(S)-\alpha$-chlorohydrin $(\mathrm{S} \alpha \mathrm{Cl})$ or $5 \mathrm{~mm}-(R, S)-3-$ chlorolactaldehyde (RS3CL)

\begin{tabular}{|c|c|c|c|c|c|}
\hline \multirow[b]{2}{*}{ Substrate } & \multicolumn{2}{|c|}{ Inhibitor (mM) } & \multicolumn{3}{|c|}{$\begin{array}{l}\text { Amount of glycolytic intermediate } \\
\text { (pmol/mg protein) }\end{array}$} \\
\hline & $\mathrm{S} \alpha \mathrm{Cl}$ & RS3CL & FBP & DHAP & G3P \\
\hline Fructose (1 mM) & $\begin{array}{c}0 \\
0 \cdot 5 \\
0\end{array}$ & $\begin{array}{l}0 \\
0 \\
5\end{array}$ & $\begin{aligned} & 3 \cdot 1 \pm 3 \cdot 0 \\
& 5330 \pm 1160 \\
& 2350 \pm 237\end{aligned}$ & $\begin{array}{l}60 \cdot 5 \pm 3 \cdot 1 \\
4020 \pm 640 \\
1610 \pm 96\end{array}$ & $\begin{array}{c}\text { n.d. } \\
558 \pm 140 \\
195 \pm 40\end{array}$ \\
\hline Glycerol (2 mM) & $\begin{array}{c}0 \\
0 \cdot 5 \\
0\end{array}$ & $\begin{array}{l}0 \\
0 \\
5\end{array}$ & $\begin{array}{l}63 \cdot 3 \pm 2 \cdot 85 \\
110 \pm 40 \\
409 \pm 174\end{array}$ & $\begin{array}{l}164 \pm 22 \cdot 4 \\
116 \pm 31 \\
264 \pm 63 \cdot 4\end{array}$ & $\begin{array}{c}\text { n.d. } \\
\text { n.d. } \\
26 \cdot 1 \pm 15 \cdot 7\end{array}$ \\
\hline Glycerol 3-phosphate (2 mM) & $\begin{array}{c}0 \\
0 \cdot 5 \\
0\end{array}$ & $\begin{array}{l}0 \\
0 \\
5\end{array}$ & $\begin{array}{r}40.4 \pm 15.6 \\
135 \pm 63.9 \\
198 \pm 83.4\end{array}$ & $\begin{array}{l}141 \pm 36 \\
206 \pm 14 \cdot 5 \\
290 \pm 50 \cdot 6\end{array}$ & $\begin{aligned} 27.7 & \pm 13.7 \\
144 & \pm 38 \\
118 & \pm 5.61\end{aligned}$ \\
\hline
\end{tabular}

Values are mean \pm s.e.m. for 4 separate experiments. n.d. = not detectable.

\section{Preincubation of spermatozoa with $(S)-\alpha$-chlorohydrin}

The oxidation of fructose was inhibited by $85 \%$ when $0.5 \mathrm{~mm}-(S)$ - $\alpha$-chlorohydrin was added at the same time as the substrate but by $95 \%$ when the $(S)$ - $\alpha$-chlorohydrin was added 2.5 min before the fructose (Table 3). $(S)$ - $\alpha$-chlorohydrin $(0.5 \mathrm{~mm})$ had no effect on the oxidation of glycerol when the two substances were added simultaneously but when the spermatozoa were preincubated with $0.5 \mathrm{~mm}-(S)-\alpha$-chlorohydrin for $2.5 \mathrm{~min}$ the oxidation of glycerol was inhibited by almost $90 \%$.

Table 3. Effect of preincubation time with $(S)$ - $\alpha$-chlorohydrin $(0.5 \mathrm{mM})$ on the oxidation of $\mathrm{D}-\left[\mathrm{U}-{ }^{14} \mathrm{C}\right]$ fructose $(1 \mathrm{mM})$ and $\left[\mathrm{U}-{ }^{14} \mathrm{C}\right] \mathrm{glycerol}(2 \mathrm{mM})$ to ${ }^{14} \mathrm{CO}_{2}$ by boar spermatozoa for $1 \mathrm{~h}$ at $34^{\circ} \mathrm{C}$

\begin{tabular}{lcccc}
\hline & \multicolumn{4}{c}{$\begin{array}{c}\mathrm{CO} \text { evolved (\% of control) } \\
\text { after preincubation for: }\end{array}$} \\
\cline { 2 - 5 } Substrate & $0 \mathrm{~min}$ & $2.5 \mathrm{~min}$ & $5 \mathrm{~min}$ & $10 \mathrm{~min}$ \\
\hline Fructose & $14.8 \pm 6.0^{*}$ & $6.64 \pm 1.43^{*}$ & $5.49 \pm 1 \cdot 56^{*}$ & $4.78 \pm 1.24^{*}$ \\
Glycerol & $104 \pm 8 \cdot 85$ & $12.7 \pm 0.001^{*}$ & $8 \cdot 14 \pm 0.525^{*}$ & $7 \cdot 70 \pm 0.001^{*}$ \\
\hline
\end{tabular}




\section{Oxidation of glycerol and $(S)-\alpha-$ chlorohydrin}

When $1 \mathrm{~mm}$-glycerol or $1 \mathrm{~mm}-(S)$ - $\alpha$-chlorohydrin were offered as substrates, the extract of aldose reductase(s) from boar spermatozoa did not show any appreciable activity as assessed by the inability to produce NADH. When $1 \mathrm{mM}-(R, S)$-glyceraldehyde or $1 \mathrm{mM}-(R, S)$-3-chlorolactaldehyde was added to the reaction cuvettes containing the extract, exogenous NADH was oxidized to $\mathrm{NAD}{ }^{+}$. The rate of this oxidation was increased by addition of $\mathrm{SO}_{4}{ }^{2-}$ which is a known stimulator of aldose reductase activity (Hers, 1962).

The dehydrogenase extract was able to oxidize both glycerol and $(S)$ - $\alpha$-chlorohydrin when $\mathrm{NADP}^{+}$was present but not when the co-factor was $\mathrm{NAD}^{+}$. There was no activity with either cofactor when $(R)$ - $\alpha$-chlorohydrin was added to the dehydrogenase preparation.

Table 4. The activity of glyceraldehyde 3-phosphate dehydrogenase isolated from boar spermatozoa incubated for $1 \mathrm{~h}$ at $34^{\circ} \mathrm{C}$ in the presence of $(S)$ - $\alpha$-chlorohydrin or $(R, S)$-3-chlorolactaldehyde with fructose $(1 \mathrm{mM})$ or glycerol $(10 \mathrm{mM})$ as the substrate

\begin{tabular}{lcc}
\hline Substrate & Inhibitor & $\begin{array}{c}\text { nmol substrate } \\
\text { oxidized/min/mg protein } \\
\text { at } 25^{\circ} \mathrm{C}(\% \text { of control })\end{array}$ \\
\hline Fructose & - & $100 \dagger$ \\
& $(S)$ - $\alpha$-chlorohydrin $(0.5 \mathrm{mM})$ & $38.5 \pm 9 \cdot 74^{*}$ \\
& $(R)-\alpha$-chlorohydrin $(10 \mathrm{mM})$ & $83.5 \pm 14 \cdot 8$ \\
Glycerol & $(R, S)$-3-chlorolactaldehyde $(5 \mathrm{mM})$ & $63.5 \pm 5 \cdot 59^{* *}$ \\
& $(S)-\alpha$-chlorohydrin $(0.5 \mathrm{mM})$ & $100 \pm$ \\
& $(R, S)$-3-chlorolactaldehyde $(5 \mathrm{mM})$ & $102 \pm 4 \cdot 14$ \\
\hline
\end{tabular}

Values are the mean \pm s.e.m. of 4 separate experiments.

$\uparrow$ Control value $5.56 \pm 1.07 \mathrm{nmol}$ substrate oxidized $/ \mathrm{min} / \mathrm{mg}$ protein.

$\ddagger$ Control value $6.72 \pm 1 \cdot 16 \mathrm{nmol}$ substrate oxidized $/ \mathrm{min} / \mathrm{mg}$ protein.

* $P<0.05,{ }^{* *} P<0.02,{ }^{* * *} P<0.01$ (Student's $t$ test).

\section{Activity of sperm glyceraldehyde 3-phosphate dehydrogenase}

Boar spermatozoa were incubated for $1 \mathrm{~h}$ at $34^{\circ} \mathrm{C}$ with fructose $(1 \mathrm{mM})$ or glycerol (10 mM) as substrates. When the spermatozoa were disrupted by sonic oscillation, the activities of glyceraldehyde 3-phosphate dehydrogenase were 5.56 \pm 1.07 and $6.72 \pm 1.16 \mathrm{nmol}$ glyceraldehyde 3-phosphate oxidized $/ \mathrm{min} / \mathrm{mg}$ protein, respectively, at $\mathrm{pH} 8.5$ and $25^{\circ} \mathrm{C}$. With fructose as the substrate, the presence of $0.5 \mathrm{~mm}-(S)$ - $\alpha$-chlorohydrin in the incubation medium reduced the activity of the enzyme by $\sim 60 \%$, whereas the presence of $10 \mathrm{~mm}-(R)-\alpha$-chlorohydrin had no significant effect (Table 4). With glycerol as the substrate, $0.5 \mathrm{~mm}-(S)-\alpha$-chlorohydrin had no significant effect on the activity of glyceraldehyde 3-phosphate dehydrogenase. In the presence of $5 \mathrm{mM}-(R, S)-3-$ chlorolactaldehyde the activity of the enzyme was reduced by $\sim 35 \%$ (fructose as substrate) and $\sim 28 \%$ (glycerol as substrate).

\section{Discussion}

Boar spermatozoa are capable of converting $(S)$ - $\alpha$-chlorohydrin into $(S)$-3-chlorolactaldehyde and this metabolite inhibits glyceraldehyde 3-phosphate dehydrogenase (Stevenson \& Jones, 1982). The conversion of $(S)$ - $\alpha$-chlorohydrin into $(S)$-3-chlorolactaldehyde was confirmed by comparing the 
effects of $(S)$ - $\alpha$-chlorohydrin and $(R, S)$-3-chlorolactaldehyde on the oxidative metabolism by boar spermatozoa of specific glycolytic substrates to $\mathrm{CO}_{2} .(S)$ - $\alpha$-Chlorohydrin inhibited the oxidation of both fructose and glycerol 3-phosphate but had no effect on the oxidation of either substrate when glycerol was present. The oxidation of glycerol was unaffected by $(S)$ - $\alpha$-chlorohydrin but the oxidation of all three substrates was inhibited by $(R, S)$-3-chlorolactaldehyde either alone or, in the case of fructose and glycerol 3-phosphate, in the presence of glycerol. These observations suggested that the presence of glycerol, but not the presence of either of its metabolites (glycerol 3-phosphate or dihydroxyacetone phosphate), was preventing the formation of $(S)$-3-chlorolactaldehyde from $(S)$ - $\alpha$-chlorohydrin. This was confirmed by preincubating spermatozoa with $(S)-\alpha$-chlorohydrin for short periods before the glycerol was added: there was considerable inhibition of the oxidative metabolism of glycerol which was increased as the preincubation time was increased.

The established pathway for the metabolism of glycerol by spermatozoa is its conversion by glycerol kinase to glycerol 3-phosphate which then produces dihydroxyacetone phosphate by an FAD-linked glycerol 3-phosphate dehydrogenase (Schenkman, Richart \& Westerfeld, 1965; Ford, 1981). However, as the activity of glycerol kinase is low in boar spermatozoa (Mohri \& Masaki, 1967), there may be an alternative pathway involving the oxidation of glycerol to glyceraldehyde which could then produce glyceraldehyde 3-phosphate. Our results can be explained if such a pathway operated in boar spermatozoa and if the enzyme responsible was able to convert $(S)-\alpha-$ chlorohydrin to $(S)$-3-chlorolactaldehyde. There are three classes of enzymes that are capable of interconverting aldehydes and primary alcohols; aldose reductases, $\mathrm{NAD}^{+}$-dependent alcohol dehydrogenases and NADP+-dependent glycerol dehydrogenases. Our preparation of aldose reductase(s) from boar spermatozoa (O'Brien \& Schofield, 1980) used glyceraldehyde and $(R, S)$-3chlorolactaldehyde as substrates but not glycerol or $(S)$ - $\alpha$-chlorohydrin. This is characteristic of this class of enzyme in which the reaction is overwhelmingly in favour of alcohol formation (Flynn, 1982). However, when boar spermatozoa were processed to yield a fraction of high dehydrogenase activity (Kormann et al., 1972), the oxidation of glycerol and $(S)$ - $\alpha$-chlorohydrin proceeded in the presence of exogenous $\mathrm{NADP}^{+}$but not in the presence of $\mathrm{NAD}^{+}$. Addition of 2,4dinitrophenylhydrazine reagent to these $\mathrm{NADP}^{+}$-catalysed reactions, in which $\left[\mathrm{U}-{ }^{14} \mathrm{C}\right]$ glycerol and $\left[3-{ }^{36} \mathrm{Cl}\right]-(R, S)-\alpha-$ chlorohydrin were the substrates, enabled the isolation of radioactive 2,4dinitrophenylhydrazone derivatives which were identified as those of, respectively, glyceraldehyde and 3-chlorolactaldehyde of unknown configuration. Since there was no reaction when $(R)-\alpha-$ chlorohydrin was offered as a substrate we propose that this conversion is specific for $(S)-\alpha-$ chlorohydrin and that the product is $(S)$-3-chlorolactaldehyde.

Therefore, an $\mathrm{NADP}^{+}$-dependent enzyme, which may be a glycerol dehydrogenase (Kormann et al., 1972), which is capable of oxidizing glycerol to glyceraldehyde and $(S)$ - $\alpha$-chlorohydrin to $(S)$ 3-chlorolactaldehyde, is present in boar spermatozoa. The involvement of glycerol in the antifertility activity of $\alpha$-chlorohydrin has been observed on many occasions. Coppola (1969) was the first to describe $\alpha$-chlorohydrin as a "metabolic antagonist" of glycerol while others suggested that it was a "toxic form of glycerol" (Gunn, Gould \& Anderson, 1969; Brown-Woodman \& White, 1976). Metabolic studies with ram spermatozoa in vitro led Brown-Woodman et al. (1978) to comment that "the relatively high concentration of $\alpha$-chlorohydrin required to inhibit the metabolism of glycerol was completely unexpected" while Edwards, Dacheaux \& Waites (1976) reported that "the presence of glycerol apparently protects spermatozoa from this damage [inhibition of glycolysis by $\alpha$-chlorohydrin], which suggests that some derivative of $\alpha$-chlorohydrin is formed by spermatozoa and is the active agent in the inhibition of glycolysis". With the demonstration that an NADP ${ }^{+}$-dependent enzyme is involved in the production of $(S)$-3chlorolactaldehyde, these observations can now be explained. Glycerol and $(S)$ - $\alpha$-chlorohydrin can probably compete as substrates for this enzyme so that the presence of glycerol would suppress the amount of $(S)$-3-chlorolactaldehyde which could be produced to a level below that which is necessary to inhibit glyceraldehyde 3-phosphate dehydrogenase.

The second process that is involved in the anti-glycolytic action of $(S)$ - $\alpha$-chlorohydrin is the 
inhibition of glyceraldehyde 3-phosphate dehydrogenase by $(S)$-3-chlorolactaldehyde. While metabolic studies have shown that the accumulation of the triose-phosphates and fructose 1,6 bisphosphate is indicative of the inhibition of this enzyme, no direct evidence has so far been produced. The activity of glyceraldehyde 3-phosphate dehydrogenase was determined in extracts of boar spermatozoa that had been incubated with fructose or glycerol as substrates. When the incubations with fructose were performed in the presence of $(S)$ - $\alpha$-chlorohydrin, the activity of the enzyme was significantly reduced although there was no effect when $(R)$ - $\alpha$-chlorohydrin was present in the incubate in higher concentrations. This can be interpreted as an inhibition of the enzyme by $(S)$-3-chlorolactaldehyde which was produced by the spermatozoa from the $(S)$ - $\alpha$ chlorohydrin. With glycerol as the carbon source, however, the presence of $(S)$ - $\alpha$-chlorohydrin had no effect on the activity of glyceraldehyde 3-phosphate dehydrogenase since the presence of glycerol would decrease the amount of $(S)$-3-chlorolactaldehyde that would be produced by the $\mathrm{NADP}^{+}$-dependent dehydrogenase. Confirmation of these proposals was obtained when the incubations were performed in the presence of $(R, S)$-3-chlorolactaldehyde: for each substrate, the activity of glyceraldehyde 3-phosphate dehydrogenase was significantly reduced.

A much higher concentration of exogenous $(R, S)$-3-chlorolactaldehyde is required to inhibit sperm glyceraldehyde 3-phosphate dehydrogenase compared to that which is produced endogenously from $(S)$ - $\alpha$-chlorohydrin. This may be due to there being a limitation on the passage of $(S)$-3-chlorolactaldehyde across the sperm membrane. Evidence for this has been obtained in a previous study which involved the incubation of boar spermatozoa with $(R, S)-\left[3-{ }^{36} \mathrm{Cl}\right]-\alpha-$ chlorohydrin (Stevenson \& Jones, 1982). $(S)-\left[3-{ }^{36} \mathrm{Cl}\right] \mathrm{Chlorolactaldehyde}$ was not detected in the supernatant solution but was present only in the supernatant solution derived from the spermatozoa after they had been disrupted by sonic oscillation. These observations have been proposed as

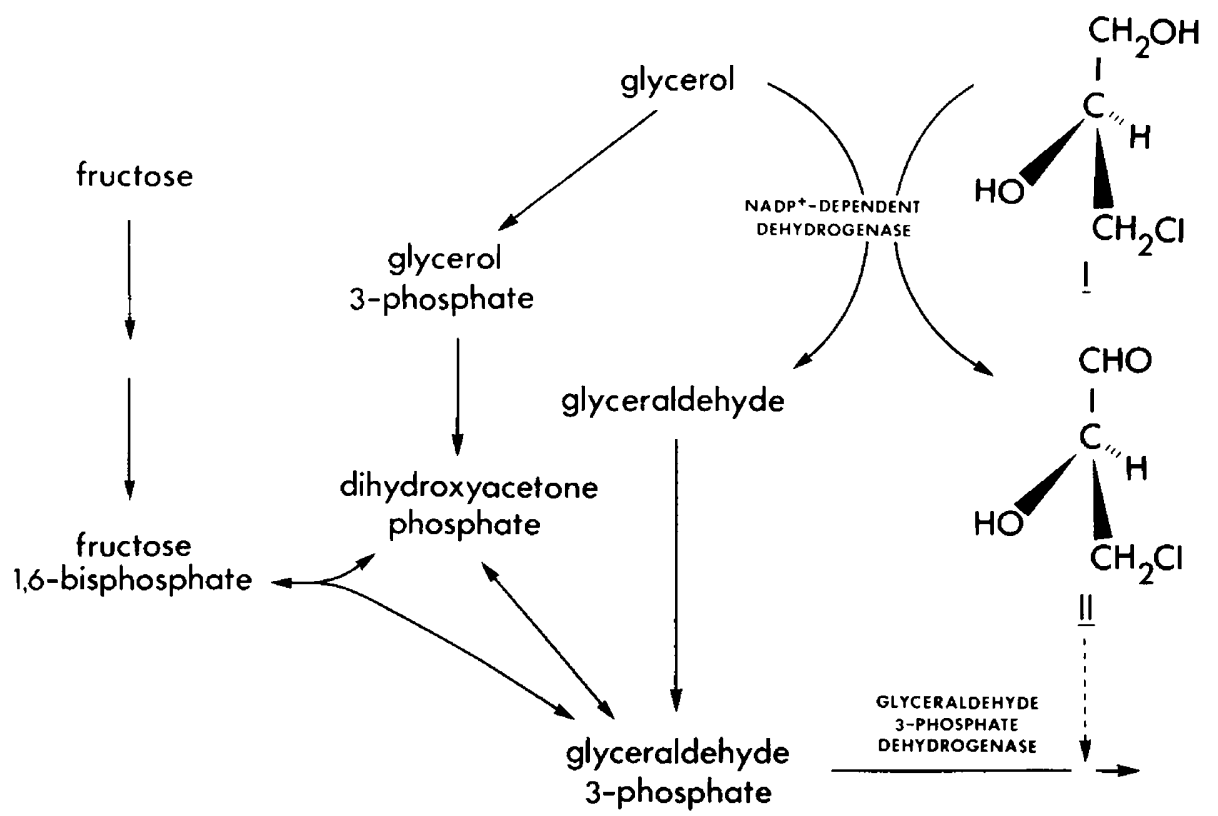

Text-fig. 2. The proposed mechanism for the antiglycolytic action of $(S)$ - $\alpha$-chlorohydrin within mature boar spermatozoa. The compound $(I)$ is oxidized to $(S)$-3-chlorolactaldehyde $(I I)$ by an $\mathrm{NADP}^{+}$-dependent dehydrogenase which converts glycerol to glyceraldehyde. The metabolite (II) inhibits glyceraldehyde 3-phosphate dehydrogenase, resulting in a decrease in the glycolytic flux and the accumulation of glyceraldehyde 3-phosphate, dihydroxyacetone phosphate and fructose 1,6-bisphosphate. 
indicating that the passage of $(S)$-3-chlorolactaldehyde across the sperm membrane is not as facile as is the case with the isomers of $\alpha$-chlorohydrin which, when incubated with boar spermatozoa, rapidly enter the cells (Stevenson \& Jones, 1982).

We propose, therefore, that the antiglycolytic activity of $(S)$ - $\alpha$-chlorohydrin in boar spermatozoa in vitro is the result of two distinct events. First, the oxidation of the compound to $(S)$ 3-chlorolactaldehyde by an $\mathrm{NADP}^{+}$-dependent dehydrogenase and second, inhibition of glyceraldehyde 3-phosphate dehydrogenase by this specific metabolite (Text-fig. 2). The speciesspecificity of $(S)$ - $\alpha$-chlorohydrin as an antifertility agent may be due to one or both events not being able to occur within the spermatozoa of a particular species. For example, the fertility of male rabbits is unaffected by administration of high doses of $(R, S)-\alpha$-chlorohydrin (Ericsson, 1970; Samojlik \& Chang, 1970) and this could be due to the inability of rabbit spermatozoa to oxidize readily $(S)$ - $\alpha$-chlorohydrin to $(S)$-3-chlorolactaldehyde (Ford \& Jones, 1983). When rabbit spermatozoa were incubated in the presence of low concentrations of $(R, S)$-3-chlorolactaldehyde, the glycolytic flux was decreased due to the specific inhibition of glyceraldehyde 3-phosphate dehydrogenase (Ford \& Jones, 1983).

This work was supported by the National Health and Medical Research Council of Australia and an Aboriginal study grant (to D.S.). We thank Sid Jarratt for technical assistance.

\section{References}

Brown-Woodman, P.D.C. \& White, I.G. (1976) A comparison of the inhibition of the metabolism of ram and rabbit spermatozoa by $\alpha$-chlorohydrin in vitro. Theriogenology 6, 29-37.

Brown-Woodman, P.D.C., Mohri, H., Mohri, T., Suter, D. \& White, I.G. (1978) Mode of action of $\alpha$ chlorohydrin as a male antifertility agent. Inhibition of the metabolism of ram spermatozoa by $\alpha$ chlorohydrin and location of block in glycolysis. Biochem. J. 170, 23-37.

Coakley, W.T. \& James, C.J. (1978) A simple linear transform for the Folin-Lowry protein calibration curve to $1.0 \mathrm{mg} / \mathrm{ml}$. Analyt. Biochem. 85, 90-97.

Coppola, J.A. (1969) An extragonadal male antifertility agent. Life Sci. 8, 43-48.

Dawson, A.G. (1977) Contribution of pH-sensitive metabolic processes to $\mathrm{pH}$ homeostasis in isolated rat kidney tubules. Biochim. Biophys Acta 449, 85-98.

Edwards, E.M., Dacheaux, J.-L. \& Waites, G.M.H. (1976) Effects of $\alpha$-chlorohydrin on the metabolism of testicular and epididymal spermatozoa of rams. $J$. Reprod. Fert. 48, 265-270.

Ericsson, R.J. (1970) Male antifertility compounds: U5897 as a rat chemosterilant. J. Reprod. Fert. 22, 213-222.

Flynn, T.G. (1982) Aldehyde reductases: monomeric NADPH-dependent oxoreductases with multifunctional potential. Biochem. Pharmacol. 31, 2705-2712.

Ford, S.A. \& Jones, A.R. (1983) The effect of $\alpha$ chlorohydrin on the oxidation of fructose by rabbit spermatozoa in vitro. Contraception 28, 565-574.

Ford, W.C.L. (1981) The oxidation of glycerol-3phosphate by testicular and epididymal spermatozoa. Comp. Biochem. Physiol. 68B, 289-293.

Ford, W.C.L., Harrison, A., Takkar, G.L. \& Waites, G.M.H. (1979) Inhibition of glucose catabolism in rat, hamster, rhesus monkey and human spermatozoa by $\alpha$-chlorohydrin. Int. J. Androl. 2, 275-288.
Gunn, S.A., Gould, T.C. \& Anderson, W.A.D. (1969) Possible mechanism of post-testicular antifertility action of 3-chloro-1,2-propanediol. Proc. Soc. exp. Biol. Med. 132, 656-659.

Hers, H.G. (1962) Aldose reductase. In Methods in Enzymology, Vol. 5, pp. 333-335. Eds. S. P. Colowick \& N. O. Kaplan. Academic Press, New York.

Hutton, P., Dawson, A.G. \& Jones, A.R. (1980) Inhibitor of glycolysis in boar sperm by $\alpha$-chlorohydrin. Contraception 22, 505-512.

Jones, A.R. (1975) The metabolism of 3-chloro-, 3bromo- and 3-iodo-propan-1,2-diol in rats and mice. Xenobiotica 5, 155-165.

Jones, A.R. (1978) The antifertility actions of $\alpha$ chlorohydrin in the male. Life Sci. 23, 1625-1646.

Jones, A.R. (1983) Antifertility actions of $\alpha$-chlorohydrin in the male. Aust. J. biol. Sci. 36, 333-350.

Jones, A.R., Stevenson, D., Hutton, P. \& Dawson, A.G. (1981) The antifertility action of $\alpha$-chlorohydrin: metabolism by rat and boar sperm. Experientia 37, 340-341.

Kormann, A.W., Hurst, R.O. \& Flynn, T.G. (1972) Purification and properties of an NADP ${ }^{+}$-dependent glycerol dehydrogenase from rabbit skeletal muscle. Biochim. Biophys. Acta 258, 40-55.

Lowry, O.H., Rosebrough, N.J., Farr, A.L. \& Randall, R.J. (1951) Protein measurement with the Folin phenol reagent. J. biol. Chem. 193, 265-275.

Michal, G. \& Beutler, H.-O. (1975) D-Fructose-1,6diphosphate, dihydroxyacetone phosphate and Dglyceraldehyde-3-phosphate. In Methods of Enzymatic Analysis, Vol. 3, pp. 1314-1319. Ed. H. U. Bergmeyer. Academic Press, New York.

Mohri, H. \& Masaki, J. (1967) Glycerokinase and its possible role in glycerol metabolism of bull spermatozoa. J. Reprod. Fert. 14, 179-194.

O'Brien, M.M. \& Schofield, P.J. (1980) Polyol-pathway enzymes of human brain. Partial purification and 
properties of aldol reductase and hexonate dehydrogenase. Biochem. J. 187, 21-30.

Porter, K.E. \& Jones, A.R. (1982) The effect of the isomers of $\alpha$-chlorohydrin and racemic $\beta$ chlorolactate on the rat kidney. Chem.-Biol. Interac. 41, 95-104.

Samojlik, E. \& Chang, M.C. (1970) Antifertility activity of 3-chloro-1,2-propanediol (U-5897) on male rats. Biol. Reprod. 2, 299-304.

Schenkman, F.B., Richart, D.A. \& Westerfeld, W.W. (1965) $\alpha$-Glycerophosphate dehydrogenase activity in rat spermatozoa. Endocrinology 76, 1055-1061.
Stevenson, D. \& Jones, A.R. (1982) Inhibition of fructolysis in boar spermatozoa by the male antifertility agent (S)- $\alpha$-chlorohydrin. Aust. J. biol. Sci. 35, 595-605.

Velick, S.F. (1955) Glyceraldehyde-3-phosphate dehydrogenase from muscle. In Methods in Enzymology, Vol. 1, pp. 401-406. Eds S. P. Colowick \& N. O. Kaplan. Academic Press, New York.

Williams, P.H., Payne, G.B., Sullivan, G.B. \& Van Ess, P.R. (1960) Chemistry of glycidaldehyde. J. Am. Chem. Soc. 82, 4883-4888.

Received 4 September 1984 